\title{
The Performance of A Diesel Engine Fueled With Diesel Oil, Biodiesel and Preheated Coconut Oil
}

\author{
Tuan Anh Hoang* and Vang Van Le
}

Ho Chi Minh University of Transport, Ho Chi Minh city, Vietnam

\begin{abstract}
Fossil fuel crisis and depletion, environmental pollution and ever-increase in vehicle and transportation means have renewed the scientist's interest in the world in order to look for potential alternative fuels, which are attractive such as biodiesel, bioethanol, DME and vegetable oils. Inedible vegetable oils such as coconut oil, Jatropha oil, linseed oil or animal fat are full of potential for using directly or manufacturing biodiesel. This work is carried out in order to study the four stroke diesel engine D240 performance characteristics fueled with preheated pure coconut oil (PCO), Jatropha oil methyl ester (JOME) and compare with diesel oil (DO). The test diesel engine performance such as power (Ne), torque (Me), specific fuel consumption (ge) and thermal efficiency (ne) is determined, calculated and evaluated while using JOME, preheated PCO and compared to DO. The results show that, power $(\mathrm{Ne})$, torque (Me) and thermal efficiency (ne) while engine is fueled with JOME and PCO are lower, otherwise specific fuel consumption (ge) is higher than those of diesel fuel, the test engine performance are gained the best for JOME and PCO100.
\end{abstract}

Keywords: biofuel, biodiesel, preheated vegetable oils, engine performance, efficiency, specific fuel consumption.

Article History: Received Dec 9, 2016; Received in revised form January 28, 2017; Accepted February 4, 2017; Available online

How to Cite This Article: Hoang, T.A and Le,V.V. (2017). The Performance of A Diesel Engine Fueled With Diesel Oil, Biodiesel and Preheated Coconut Oil. International Journal of Renewable Energy Development, 6(1), 1-7.

http://dx.doi.org/10.14710/ijred.6.1.1-7

\section{Introduction}

At present, the depletion of fossil fuel stores in the world and the environmental pollution due to everincreasing exhaust emissions from internal combustion engine are the urgent matters, which promote to develop alternative energy and fuel resources such as biofuels in order to gradual replacement for diesel fuel.

Vegetable oil shows potential and promising alternative fuel because of its advantages, which are renewable, friendly environment, easy in producing, biodegradable. Moreover, the products based on vegetable oil will be potential for stimulating the development of rural economic. Hence, in current years, many researchers have been carried out, studied and find many methods to improve the disadvantages of pure vegetable oils such as high viscosity in order to use directly as fuel in diesel engines (Pramanik, 2003). However, biodiesel is defined as monoalkyl esters of fatty acids. It is also considered as a clean, biodegradable, available and renewable fuel. Biodiesels are produced by the transesterification from vegetable oils or animal fats, which contain unsaturated or saturated fat sources, with ankanol but primarily from methanol or ethanol (Gerhard, 2005). In Vietnam, ordinary sources for producing biodiesel are peanut oil, soybean oil, catfish fat, jatropha and coconut oil. In general, some advantages of biodiesel such as its renewable, flammable safety and nontoxic, emission reduces. Therefore, biodiesel has used significantly for many years. The Vietnamese Prime Minister has issued a decision No.177 on "Project development of biofuels with the orientation to 2025". Generally, the heating value of pure vegetable oils and biodiesels are lower, otherwise their viscosities, surface tension and densities are higher than those of diesel fuel. Many researchers prove that the pure vegetable oils and biodiesels are used at 100\% (V0100 \& B100) or blend of diesel fuel for diesel engine. However, the power of diesel engine using V0100 or B100 in comparison with diesel fuel reduces lightly otherwise increasing of $\left(\mathrm{g}_{\mathrm{e}}\right)$. Besides some advantages of pure vegetable oils (V0100) and biodiesels (B100), several researches also propound the concerns about the lubricating oil deterioration,

* Corresponding author: anhtuanhoang1980@gmail.com 
which will increase certainty the abrasion of moving machinery parts such as piston in combustion chamber while operating diesel engine in long time with V0100 and B100. Furthermore, the appearance the deposit on the injectors, pistons and cylinder head are necessary and major causes to consider using and operating the diesel by V0100 and B100.

In Vietnam, the production of pure vegetable oils in 2012 was 709.000 tons and will 1.929.000 tons in 2025. From the genetic fund of oil plants with hundreds of seed samples, after years of research, Vietnam has selected and crossbred several varieties oil plants with high-yield, good quality. These varieties have contributed significantly to the expansion of the areas, improve productivity, quality and economic efficiency of the oil plants, especially used in manufacturing biofuels such as biodiesel, bio-oil, etc. They can be identified as follows:

- Peanut (Arachis hypogaea): The peanut varieties give grain yield from 3000-4000 kgs/ha/crop, they are suitable for climatic conditions and soil in the Southern provinces. These varieties currently are growing popularly in manufacturing and among top 10 of varieties cultivated on the largest area of Vietnam.

- Soybean (Glycine max): The soybean varieties give average grain yield from 1600-2500 kgs of seeds/ha/crop, they are suitable for growing in the South East region and Mekong Delta. Sunflower (Helianthus annuus L.): Just 38 Hysun sunflower seed give grain yield from 2700 - 3300 $\mathrm{kgs} / \mathrm{ha} / \mathrm{crop}$, oil yield 1300-1400 kgs/ha, it is suitable for growing in Southern Highlands and Northern Mountains.

- Jatropha (Jatropha curcas): Some features of scientific research in Vietnam is to focused on the development of raw oil plants serving as fuel for the purpose of green energy programs, to reduce environmental pollution. The 41 varieties of Jatropha are assessing growth and development, grain yield, oil yield and economic efficiency. The Jatropha varieties have the oil content with the average of $31-37 \%$, as materials suitable for biofuel production.

- Coconut (Cocos nucifera L.) give grain yield 100150 fruits/tree/year, $65-67 \%$ oil content. The gene bank of coconut trees with 51 samples were collected in Vietnam and abroad, has been included in the list IPGRI Coconut international varieties.

However, biodiesels in Vietnam is manufactured mainly from fat of catfish, straw and Jatropha oil, which are available in the South and Middle of Vietnam. They are the kind of inedible animal fat and plant oil, hence using them to manufacture biodiesel will not effect on and threaten to food security. The Vietnamese Government was used the standard of B5 (5\% biodiesel and $95 \%$ diesel fuel) for diesel engine and the using of B5 is developing sharply. However, in a survey, biodiesels were manufactured 250.000 tons/year in 2015 and only met $1 \%$ of demand in using biodiesels. Therefore, the policy of the Vietnamese Government is to manufacture 1.8 million tons/year in 2025 to meet $5 \%$ of demand in using biodiesels. The most important matter in using and development in Vietnam is biodiesel price, which is the cost of input raw materials, such as electricity, vegetable oils, animal fat and methanol, additives. The biodiesel prices flux from 50.000 VNĐ to 70.000 VNĐ per a liter depending on the kind of biodiesel and the prices of biodiesel from Jatropha oil are lowest and thank to the Vietnamese Government' policy, this biodiesel are encouraged to produce and use aiming reduction of environment pollution emission in the urban.

Base on analyzing the potential in manufacturing and using bio-fuel, this study uses preheated pure coconut oil (PCO) and Jatropha oil methyl ester (JOME) for a diesel engine. The obtained results about engine performance are compared to those of diesel fuel in order to find the most suitable heating temperature for PCO and supply more the proof for using bio-oil, biodiesel as alternative fuel.

\section{Materials and Methods}

\subsection{Materials}

Vegetable oils are triglycerides and biodiesel is esters of fatty acid with ankanol, which primarily are methanol or ethanol. Many vegetable oils and biodiesel can be used to replace diesel fuel. In this study, pure coconut oil (PCO), and biodiesel from Jatropha oil (Jatropha oil methyl ester - JOME) are used to be the studied objects. Properties of PCO and JOME available in Vietnam are given in Table $1 \mathrm{a}$ and the fuel requirement met Vietnamese standard is given in Table $1 \mathrm{~b}$.

Table 1a.

Physical properties of PCO and JOME samples and diesel fuel at $30^{\circ} \mathrm{C}$

\begin{tabular}{lcccc}
\multirow{2}{*}{ Fuels } & \multicolumn{4}{c}{ Physical properties } \\
\cline { 2 - 5 } & $\boldsymbol{\mu}$ & $\boldsymbol{\sigma}$ & $\boldsymbol{D}$ & CN \\
\hline PCO & 33.5 & 0.034 & 0.91 & 40 \\
JMOE & 5.5 & 0.030 & 0.88 & 52 \\
Diesel fuel & 4 & 0.026 & 0.85 & 45 \\
\hline
\end{tabular}

Table 1b.

Vietnamese standard for diesel fuel properties at $30^{\circ} \mathrm{C}$

\begin{tabular}{lcc}
\hline Fuel properties & $\begin{array}{c}\text { Method } \\
\text { (ASTM) }\end{array}$ & $\begin{array}{c}\text { Vietnamese } \\
\text { standard }\end{array}$ \\
\hline Kinematic viscosity, $\mathrm{mm}^{2} / \mathrm{s}$ & $\mathrm{D} 445$ & $2-4.5$ \\
Surface tension, $\mathrm{mN} / \mathrm{m}$ & $\mathrm{D} 971$ & $\mathrm{Nr}$ \\
Density, g/cm ${ }^{3}$ & $\mathrm{D} 1298$ & 0.85 \\
Cetane number & $\mathrm{D} 613$ & $\geq 40$ \\
\hline
\end{tabular}

Nr: Non-requirement

Table $1 \mathrm{a}$ and $1 \mathrm{~b}$ shows that, the properties of PCO are much different from diesel fuel otherwise the properties 
of JOME are closer to diesel fuel. It can be clearly seen at $30^{\circ} \mathrm{C}$ that, cetane number $(\mathrm{CN})$ of PCO is about $12 \%$ lower but $\mathrm{CN}$ of JOME is $15 \%$ higher than that of diesel fuel. Besides, kinematic viscosity $(\mu)$ of PCO is about 8 times higher but $\mu$ of JOME is slightly higher than that of diesel fuel. Density (D) is about $9 \%$ with PCO and about $3 \%$ with JOME, surface tension $(\sigma)$ is $27 \%$ with PCO and about 15\% with JOME higher than those of diesel fuel. These occur due to the differences in the structures of PCO and JOME compared to diesel fuel, primarily the acid unsaturation degree or double bonds of carbon $(-\mathrm{C}=\mathrm{C}-)$. The higher viscosity, higher surface tension and density of the PCO and JOME will result in difficulty in fuel spray, atomization, breakup and mixture, hence they will effect on the diesel engine performance and emission. However, the disadvantages of PCO and JOME can be overcome by heating method, which is used in this study to improve some properties of PCO and JOME.

\subsection{Methods}

Some of studies denoted that, heating method is considered as the most useful and simple one to improve the disadvantages about viscosity, density of vegetable oils and biodiesel. Such as Acharya et.al (2011) used Kusum and Karanja oil's that is preheated up $100^{\circ} \mathrm{C}-$ $130^{\circ} \mathrm{C}$ for engine. Dinesh $\mathrm{P}(2012)$ used preheated POME and blend of diesel fuel up to $60^{\circ} \mathrm{C}, 75^{\circ} \mathrm{C}$ and $90^{\circ} \mathrm{C}$ in order to compare to diesel fuel while use as fuel in diesel engines. A K Hussain (2012) used preheated neat jatropha and Kharanja oil and concluded that, viscosity of the selected vegetable oils is reduced by $80 \%-90 \%$ by preheating to $90^{\circ} \mathrm{C}$. In the fact that, the relationship between some properties of PCO, JOME and temperature in this work are shown in Table 2.

Table 2.

Viscosity, surface tension and density of PCO at different temperature

\begin{tabular}{cccc}
\hline $\begin{array}{c}\text { Temperature } \\
\left({ }^{\circ} \mathbf{C}\right)\end{array}$ & $\begin{array}{c}\boldsymbol{\mu} \\
(\mathbf{c S t})\end{array}$ & $\begin{array}{c}\mathbf{D} \\
\left(\mathbf{g} / \mathbf{c m}^{3}\right)\end{array}$ & $\begin{array}{c}\boldsymbol{\sigma} \\
(\mathbf{m N} / \mathbf{m})\end{array}$ \\
\hline 40 & 28.1 & 0.9033 & 33.5 \\
50 & 20.1 & 0.8965 & 32.2 \\
60 & 14.9 & 0.8896 & 31.2 \\
70 & 11.3 & 0.8827 & 30.3 \\
80 & 9.1 & 0.8761 & 29.3 \\
90 & 7.2 & 0.8698 & 28.4 \\
100 & 5.4 & 0.8639 & 27.2 \\
110 & 4.5 & 0.8568 & 26.6 \\
\hline
\end{tabular}

\section{Determination method of $g_{e}(\mathrm{~kg} / \mathrm{kW} . \mathrm{h})$}

A test engine with an outside fuel tank and a truthful balance for measuring the mass flow of fuel $\mathrm{G}$ (kg/s) duration of time test are used in this experiment setup. All equipment is installed on the testbed to determine $\mathrm{g}_{\mathrm{e}}$ of diesel engine through G. Thanks to the measurement, the fuel mass flow $G$ is calculated through fuel supplied to engine $\left(\mathrm{G}_{\mathrm{s}}\right)$ and fuel returned from engine $\left(\mathrm{G}_{\mathrm{r}}\right)$ as the equation:

$$
G=\frac{G_{s}-G_{r}}{t}
$$

The $g_{e}$ of engine is a obtained parameter while engine supplies a power of $1 \mathrm{~kW}$ with the fuel mass $\mathrm{G}$ in a unit of time. Thus, $g_{e}$ is calculated through $G$ and engine power $\left(\mathrm{N}_{\mathrm{e}}\right)$ as:

$$
g_{e}=\frac{3600 G}{N_{e}}
$$

\section{Determination method of efficiency $\left(\eta_{e}\right)$}

HHVs of diesel fuel, PCO and JOME are determined by experiment of physical method based on ASTM D240, which diesel fuel, PCO and JOME samples are put in the combustion chamber for combusting completely. The calorie value of fuel effects on the engine performance, thus it is necessary to determine the fuel higher heating value (HHV) of fuel and for diesel fuel, and biodiesel from Jatropha and PCO using a calorimeter, which also called the bomb calorimeter and shown in Fig.1.

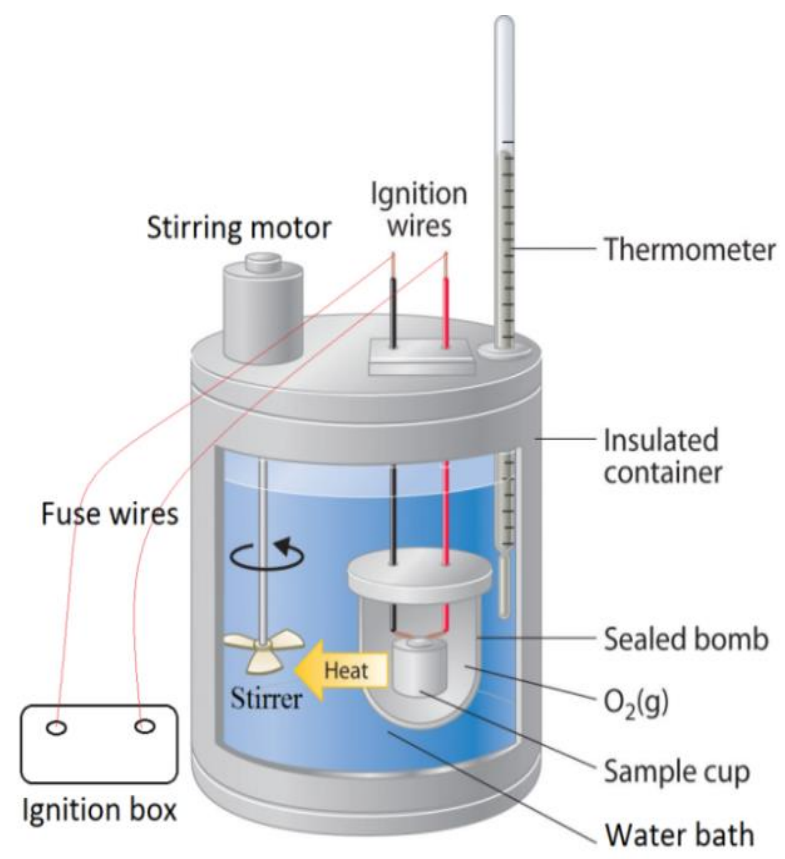

Fig 1. Schematic of bomb calorimeter

The bomb calorimeter, which contains 0.5 gram of test fuel in combustion chamber and at 30 atm of pressure, includes a sealed bomb connected to the ignition wire to fire completely the test fuels in order to determine HHV. Three fuel samples (diesel fuel, JOME, PCO) with three determinations for a sample and average result of three determinations are carried out aiming getting the accuracy results.

However, the lower heating value (LHV) of fuel is used to determine the fuel energy because LHV shows 
Citation: Hoang, T.A and Le,V. V. (2017) The Performance of a Diesel Engine Fueled With Diesel Oil, Biodiesel and Preheated Coconut Oil. Int. Journal of Renewable Energy Development, 6(1), 1-7, doi.org/10.14710/ijred.6.1.1-7

$\mathrm{P}$ a g e $\mid 4$

the energy efficient released by combusting a particular quantity of fuel mass unit. In the Volpato et al' opinion, LHV is related to HHV as Eq. (3) and is given in Table 3:

$$
L H V=H H V-3.052
$$

Table 3.

LHV of PCO and JOME samples compared to diesel fuel

\begin{tabular}{|cccc|}
\hline Fuel & PCO & JOME & Diesel oil \\
\hline HHV (MJ.kg-1) & 40.5 & 42 & 46 \\
LHV (MJ.kg-1) & 37.45 & 38.95 & 42.95 \\
\hline
\end{tabular}

Table 3 shows that, The LHV of PCO (37.45 MJ.kg-1) is $9.3 \%$ and the LHV of JOME (38.95 MJ.kg-1) is $12.8 \%$ lower than that of diesel oil (42.95 MJ.kg-1). In the diesel engine, the efficiency $\left(\eta_{\mathrm{e}}\right)$ characterizes the level of converting the combustion-created-fuel energy (E) in comparison with obtained engine power $\left(\mathrm{N}_{\mathrm{e}}\right)$. The fuel energy $(\mathrm{E})$ is determined as:

$$
E=G . L H V
$$

Therefore, the efficiency $\left(\eta_{\mathrm{e}}\right)$ is calculated as Eq (5)

$$
\eta_{e}=\frac{N_{e}}{E}=\frac{3600}{\left(g_{e}\right)(L H V)}
$$

\subsection{Test diesel engine procedure}

A diesel engine D240 is used in order to compare the performance and emission characteristic while fueled JOME and preheated PCO. Table 2 shows that, the suitable temperature of PCO to get kinematic viscosity, surface tension and density similarly to diesel fuel's is $100^{\circ} \mathrm{C}-110^{\circ} \mathrm{C}$. However, heated PCO up to respectively $80^{\circ} \mathrm{C}, 100^{\circ} \mathrm{C}$ and $120^{\circ} \mathrm{C}$ (abbreviated PCO80, PCO 100 and PC0120) in this work are used to evaluate and compare exactly to JOME and diesel oil (DO) at room temperature. The engine D240, which can be used in agricultural field or generator set, was considered as a testing object. The technical parameters of D240 diesel engine are given in Table 4 and the schematic of experiment procedure is shown in Fig.2.

The engine D240 is supplied heated PCO (include PC080, PC0100, PC0120 and JOME) with original conditioning lubricant and cooling systems similar to the case of using DO in order to maintain and ensure the stability condition of the whole testing during for experiments. The fuels such as PC080, PC0100, PC0120, JOME and DO are tested at full load at and 1000, 1200, $1400,1500,1600,1800$ and $2000 \mathrm{rpm}$ of engine speed. The fuel rate supplied to the test engine is adjusted in order to maintain the engine torque. The fuel for each test is repeated 3 times to get the average results to reduce the uncertainty.
Table 4.

Specifications of diesel engine D240

\begin{tabular}{lcc}
\multicolumn{1}{c}{ Description } & Unit & Quantity \\
\hline Power & HP & 80 \\
Maximum revolution & rpm & 2200 \\
Number cylinders & - & 4 \\
Bore & $\mathrm{mm}$ & 110 \\
Stroke & $\mathrm{mm}$ & 125 \\
Compression ratio & - & $16.5: 1$ \\
Fuel consumption & g/HP.h & 180 \\
\hline
\end{tabular}

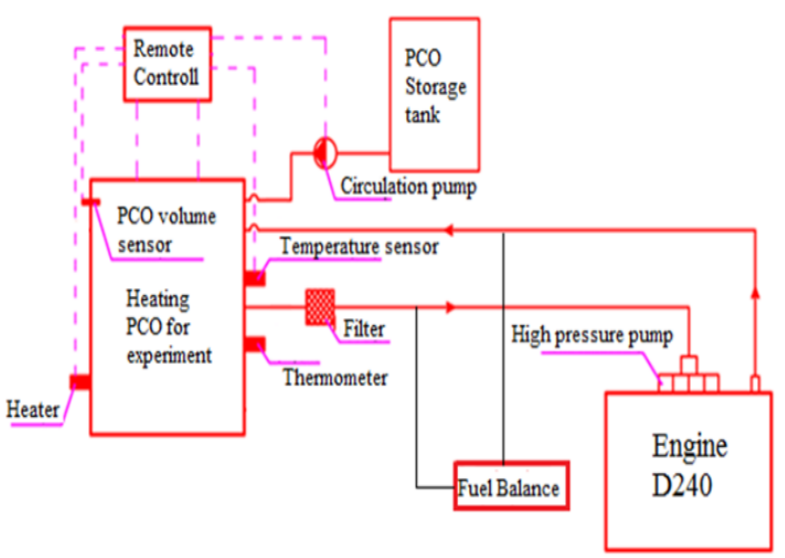

Fig 2. Schematic of experiment procedure for engine D240

\section{Results and discussions}

\subsection{Torque $\left(M_{e}\right)$ and power $\left(N_{e}\right)$ performance}

The torque $\left(\mathrm{M}_{\mathrm{e}}\right)$ performance of the D240 diesel engine with $100 \%$ load for D0, PC080, PC0100, PC0120 and JOME is presented in Fig.3.

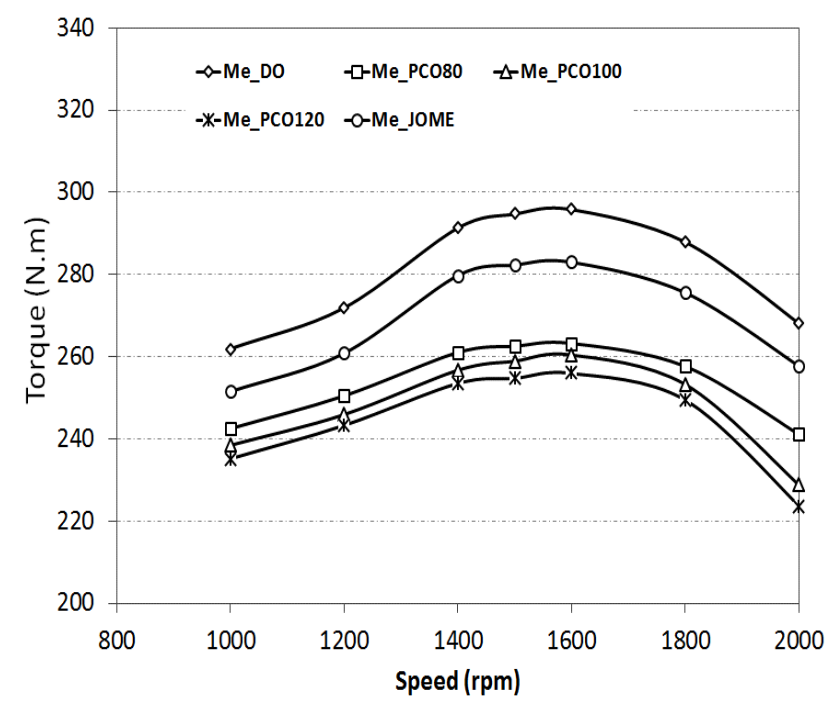

Fig 3. Diesel engine D240 torque performance at $100 \%$ load 
The obtained maximum torque is at around of 1600 $\mathrm{rpm}$. The obtained torque in case of using JOME as fuel is $3.94 \%-4.34 \%$ lower than that of DO and in case using PC080, PC0100 and PC0120 are reduced respectively by 7.38\%-11.03\%, 8.92\%-14.63\% and $10.21 \%-16.58 \%$ in comparison with DO because of lower LHV of PCO and JOME than that of DO. However, torque of PCO80 is higher than that of PC0100 and PC0120 due to the PCO80 density is higher hence the fuel mass is also higher although the same injection volume.

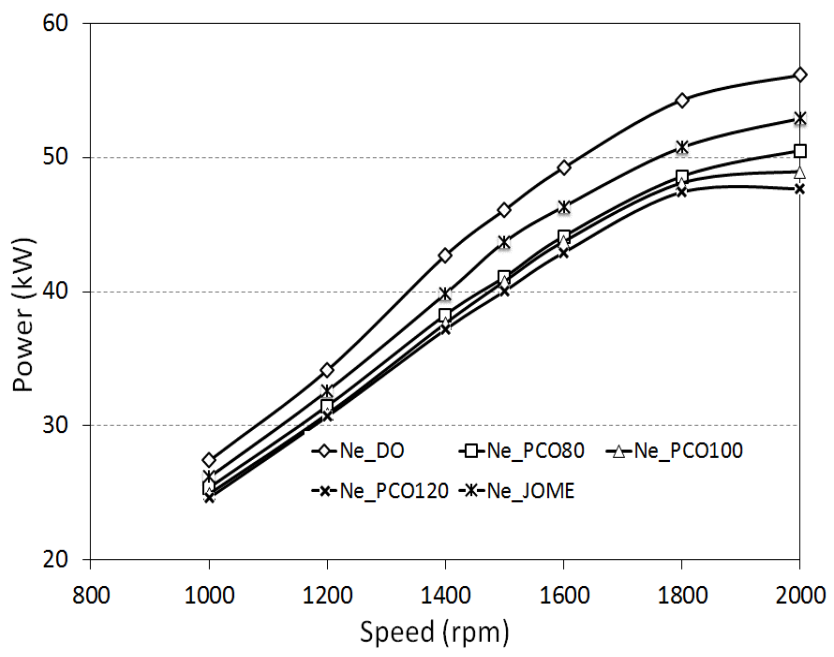

Fig 4. Diesel engine D240 power performance at $100 \%$ load

Fig.4 shows that the change of the D240 engine power $\left(\mathrm{N}_{\mathrm{e}}\right)$ performance when fueled with DO, preheated PCO and JOME is the same rule. When the temperature range from $80^{\circ} \mathrm{C}$ to $120^{\circ} \mathrm{C}$ for $\mathrm{PCO}$, the value of engine power tends to decrease due to the trend of PCO density change is inversely proportional to the temperature, this leads to reduction in the mass of PCO fuel supplied to the engine. Moreover, the LHV of the PCO and JOME are lower than that of DO. On the whole of engine speed range, corresponding to fuel PC080, PC0100, PCO120 and JOME, engine power is reduced respectively from $7.37 \%-10.91 \%$, from $8.91 \%-12.85 \%$, from $10.15 \%$ $13.17 \%$ and from $4.41 \%-6.64 \%$ in comparison with the case of using DO; the average results on the speed range, the reduction level of power is respectively $9.65 \%$; $11.06 \% ; 12.44 \%$ and $5.53 \%$.

\subsection{Specific fuel consumption performance, $g_{e}$}

The specific fuel consumption performance ( $g_{e}$ ) with $100 \%$ load at different revolution for DO, preheated PCO and JOME is shown in Fig.5. For five kind of tested fuels, ( $\left.g_{e}\right)$ decreases at low engine speed and reaches the minimum value in the revolution of $1500 \mathrm{rpm}$ and $\left(\mathrm{g}_{\mathrm{e}}\right)$ of DO is $249.16 \mathrm{~g} / \mathrm{kW} . \mathrm{h},\left(\mathrm{ge}_{\mathrm{e}}\right.$ ) of PCO80 is $312.34 \mathrm{~g} / \mathrm{kW} . \mathrm{h},\left(\mathrm{ge}_{\mathrm{e}}\right)$ of PCO100 is $307.28 \mathrm{~g} / \mathrm{kW} . \mathrm{h},\left(\mathrm{g}_{\mathrm{e}}\right)$ of PCO120 is 314.21 $\mathrm{g} / \mathrm{kW} . \mathrm{h}$ and $\left(\mathrm{g}_{\mathrm{e}}\right)$ of JOME is $280.23 \mathrm{~g} / \mathrm{kW} . \mathrm{h}$. For PCO, ( $\left.\mathrm{g}_{\mathrm{e}}\right)$ of PC0100 is the lowest value and $\left(\mathrm{g}_{\mathrm{e}}\right)$ of PCO80 is the largest, this difference is due to the mass of PCO at $80^{\circ} \mathrm{C}$ is higher than at $100^{\circ} \mathrm{C}$ and $120^{\circ} \mathrm{C}$ in comparison with achieved power engine. Further, the process of mixture formation and combustion occurred in the engine with PCO at different heating temperatures are different. For JOME, ( $g_{e}$ ) is higher than that of DO and lower than that of PCO because LHV of JOME is higher than that of PCO and lower than that of DO otherwise the density of JOME is lower than that of PCO and higher than that of DO. At full load, ( $g$ e)s of PCO80, PCO100, PC0120 were respectively $\quad 13.89 \%-20.19 \%, \quad 12.84 \%-18.97 \%$, $14.92 \%-20.75 \%$ higher than that of DO. In case of JOME, ( $g_{e}$ ) is $6.62 \%-11.26 \%$ higher than that of DO. This observed trend is due to an increase of the LHV for biodiesel in comparison with PCO and reduction for biodiesel and PCO in comparison with DO. Similar trends of ( $g_{e}$ ) are also reported by Marcelo Jose' da Silva (2013) and Ramadhas AS (2005).

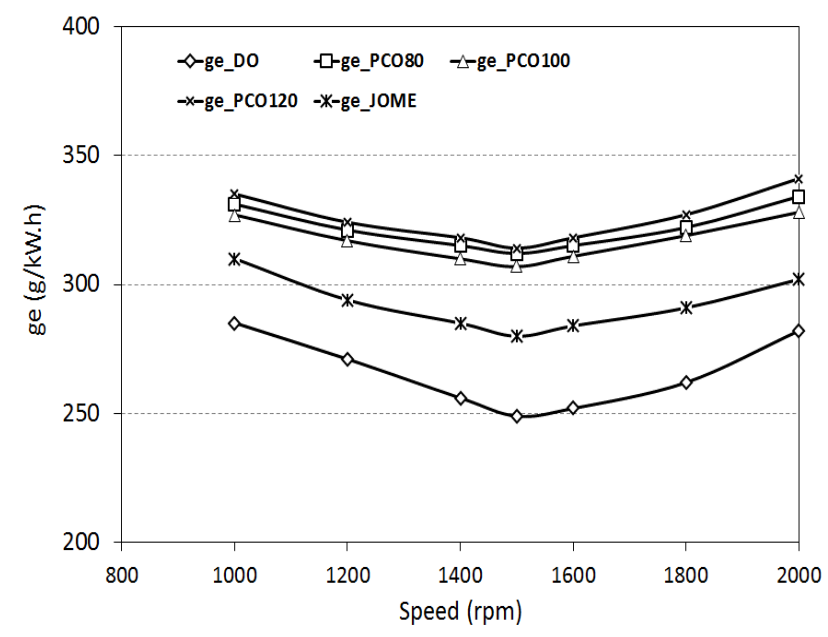

Fig 5. Diesel engine D240 specific fuel consumption performance at $100 \%$ load

\subsection{Thermal efficiency $\left(\eta_{e}\right)$}

The $\left(\eta_{\mathrm{e}}\right)$ of $\mathrm{D} 240$ engine for five kind of different fuels at $100 \%$ load is shown in Fig. 6 and Fig. 7 shows the $\left(\eta_{\mathrm{e}}\right)$ of D240 engine as a function of load at $2000 \mathrm{rpm}$. It can be seen from Fig. 6 and Fig.7 that, for PCO, the maximum $\left(\eta_{\mathrm{e}}\right)$

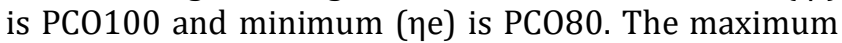
difference of $\left(\eta_{\mathrm{e}}\right)$ in using preheated $\mathrm{PCO}$ as fuel is 3.05\% in comparison with DO. According to Eq. (5) and at full load, although the LHV of JOME is 3.85\% higher than that of preheated PCO but the $\left(\mathrm{g}_{\mathrm{e}}\right)$ of JOME is $37.21 \%$ of minimum lower than that of PCO100, hence the $\left(\eta_{e}\right)$ of D240 engine fueled with JOME is higher than that of preheated PCO and slight lower than that of DO. The maximum difference of $\left(\eta_{e}\right)$ in using JOME as fuel is $0.72 \%$ in comparison with DO. 


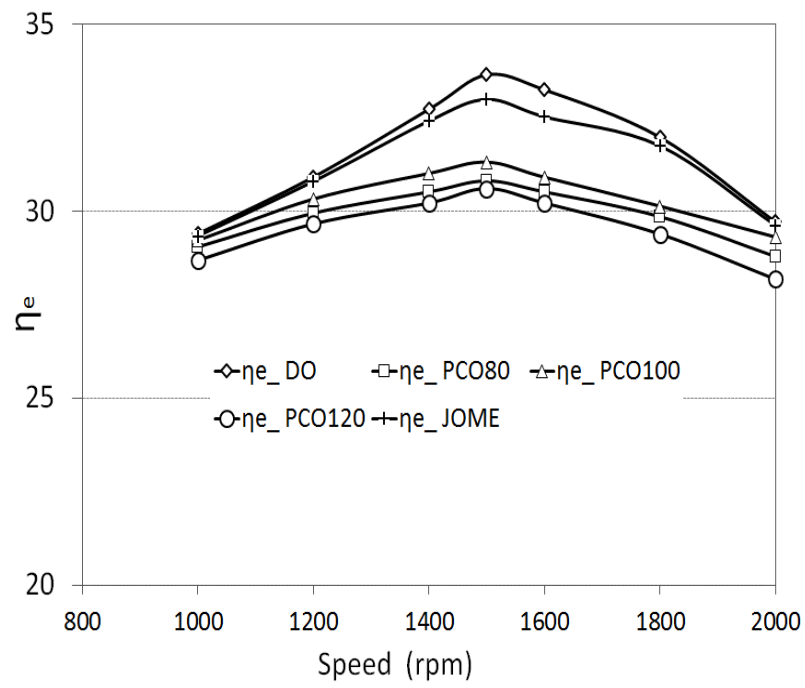

Fig 6. Diesel engine D240 thermal efficiency at $100 \%$ load

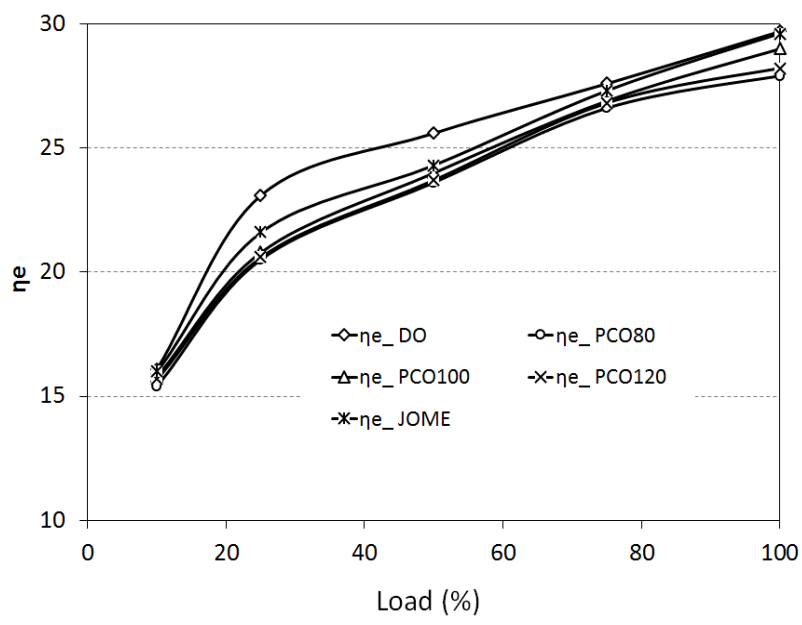

Fig 7. Diesel engine D240 thermal efficiency at $2000 \mathrm{rpm}$

Fig.7 shows that, the $\left(\eta_{\mathrm{e}}\right)$ of D240 engine increases proportional to increase in load at $2000 \mathrm{rpm}$. Based on experiment results, it can be concluded that, the engine $\left(\eta_{\mathrm{e}}\right)$ with JOME and PCO100 are comparable to that of DO and it is suitable for the reported findings of many researchers such as Marcelo Jose' da Silva (2013) and Ramadhas, A.S (2005).

\section{Conclusions}

The diesel engine performance using pure biodiesel of Jatropha (JOME), preheated pure coconut oil (PCO) are carried out by the experiment on the testbed of D240 diesel engine. The results of study are summed up as follows:

- JOME can be direct used in diesel engines to replace diesel oil, however, the best results for PCO is preheated up to $100^{\circ} \mathrm{C}$. Thus, there are no any fuel system modifications with JOME and it is necessary to install a heating system for PCO.

- The power $\left(\mathrm{N}_{\mathrm{e}}\right)$ and torque of test diesel engine are reduced slightly with JOME and much with PCO, otherwise the increase in specific fuel consumption ( $\mathrm{g}_{\mathrm{e}}$ ) is $11.26 \%$ of maximum when using JOME and is $20.75 \%$ of maximum when using PCO120 as alternative fuel.

- The thermal efficiency $\left(\eta_{\mathrm{e}}\right)$ of JOME is higher than PCO but still lower than DO. However, for PCO the thermal efficiency $\left(\eta_{\mathrm{e}}\right)$ of PCO100 is the highest.

\section{Acknowledgments}

The authors are pleased to acknowledge Ho Chi Minh University of Transport, School of Transportation Engineering - Hanoi University of Science and Technology, National Key Laboratory for Refining and Petrochemical Technologies for supporting this research.

\section{References}

Agarwal, A.K., Das, L.M. (2001) Biodiesel development and characterization for use as a fuel in compression ignition engines. Trans ASME,123, 440-447.

Ayhan, D. (2007) Biodiesel. A Realistic Fuel Alternative for Diesel Engines.

Canakci, M., Van Gerpen, J.H. (2003) Comparison of engine performance and emissions for petroleum diesel fuel, yellow grease biodiesel and soybean oil biodiesel. Trans ASAE, 46, 937-944.

David, Y.Z.C., Jon, H.V., Inmok, L., Lawrence, A.J., Earl, G.H., Stephen, J.M. (1996) Fuel properties and emissions of soybean oil esters as diesel fuel. JAOCS, 73, 1549-1555.

Dorado, M.P., Cruz, F., Palomar, J.M., López, F.J. (2006) An approach to the economics of two vegetable oil based biofuels in Spain. Renewable Energy, 31, 1231-1237.

Ekrem, B. (2010) Effects of biodiesel on a DI diesel engine performance, emission and combustion characteristics. Science Direct, 89, 30993105.

Fathima, J., Selva, I.P., Lima, R.M. (2011) Fatty esters from vegetable oils for use as a diesel fuel. IEEE Conference on Clean Energy and Technology (CET).

Gerhard, K., Jon, V.G. (2005) The Biodiesel Handbook.

http://catalog.flatworldknowledge.com/bookhub/4309?e=averill_1.0ch05_s03 Accessed on 17 September 2016

Kadu, S.P., Sarda, R.H. (2010) Experimental Investigations on the Use of Preheated Neat Karanja Oil as Fuel in a Compression Ignition Engine, Engineering and Technology, 540-544.

Kasteren, J.M.N.V., Nisworob, A.P. (2007) A process model to estimate the cost of industrial scale biodiesel production from waste cooking oil by supercritical transesterification. Resources, Conservation and Recycling, 50, 442-458.

Kyle, W.S., Spencer, C.S. (1993) Combustion of soybean oil methyl ester in a direct injection diesel engine. SAE Technical Paper, 930-934.

Marcelo, J.da.S, Samuel, N.M.S., LuizIna', C., Helton, A.R., Deonir, S., Reginaldo, F.S., Reinaldo, A.B., Carlos, E.C.N. (2013) Comparative analysis of engine generator performance using diesel oil and biodiesels available in Parana' State, Brazil. Renewable and Sustainable Energy Reviews, 17, 278-282.

Michael, J.H., Andrew, J.M., Winnie, C.Y., Thomas, A.F. (2006) A process model to estimate biodiesel production costs. Bio-resource Technology, 4, 671-678. 
Michael, S.G., Robert, L.M. (1998) Combustion of fat and vegetable-oil derived fuels in diesel engines. Progress Energy Combus SCI, 24, 125-164.

Misra, R.D., Murthy, M.S. (2010) Straight vegetable oils usage in a compression ignition engine - A review. Renewable and Sustainable Energy Reviews, 14, 3005-3013.

Murugesan, A., Umarani, C., Subramanian, R., Nedunchezhian, N. (2009) Biodiesel as an alternative fuel for diesel engines - A review. Renewable and Sustainable Energy Reviews, 13, 653-662.

Pramanik, K. (2003) Properties and use of jatropha curcas oil and diesel fuel blends in compression ignition engine. Renewable Energy, 28, 239-248.

Prasad, C.M.V., Krishna, M.V.S.M., Reddy, C.P., Mohan, K.R. (2000) Performance evaluation of non-edible vegetable oils as substitute fuels in low heat rejection diesel engines. Proceedings of the
Institution of Mechanical Engineers, Part D: Journal of Automobile Engineering, 214, 181-187.

Raheman, H., Phadatare, A.G. (2004) Diesel engine emissions and performance from blends of karanja methyl ester and diesel. Biomass Bioenergy, 27, 393-397.

Ramadhas, A.S., Muraleedharan, C., Jayaraj S. (2005) Performance and emission evaluation of a diesel engine fueled with methyl esters of rubber seed oil. Renewable Energy, 30, 1789-1800.

Sigar, C.P., Soni, S.L., Mathur, J., Sharma, D. ( 2008) Performance and emission characteristics of vegetable oil as diesel fuel extender. Energy Sources, Part A: Recovery, Utilization, and Environmental Effects, 31, 139-148.

Wassell, C.S., Dittmer, T.P. (2006) Are subsidies for biodiesel economically efficient. Energy Policy, 34, 3993-4001. 